\title{
Post-crisis, post-devolution politics and the mansion tax
}

\section{Dr Helen Thompson \\ Department of Politics and International Studies \\ University of Cambridge \\ $<$ het2o@cam.ac.uk>}

Governments across the developed world still face acute fiscal difficulties. Even where, as in Britain, there has been a return to sustained moderate economic growth, the recovery has not produced a comparable rise in tax revenue. Despite the rise in employment in the British economy since 2011, tax receipts from income tax have fallen substantially. A recovery in significant part based on part-time jobs and selfemployment has not, and cannot, repair Britain's fiscal hole, particularly since the Coalition government has raised the tax-free allowance on income. Internationally governments have made little progress on cooperative measures to address the revenue lost to tax havens and aggressive tax avoidance.

Yet with tax revenue depressed since the crisis global wealth has soared such that it now stands 39 per cent higher than it did in 2008 and 20 per cent higher than its pre-crisis peak. Indeed, Credit Suisse concluded in its 2014 Global Wealth Report that 'it seems likely that personal wealth has recently been rising at the fastest rate ever recorded'. ${ }^{1}$ This rise in wealth has benefitted almost exclusively the extremely rich, pushing the proportion of global wealth owned by the top one per cent to around 50 per cent. Whilst the rise in wealth inequality over the past decade or so has been sharpest in emerging-market economies, a number of European states, including Britain, have also seen a significant increase. The political ramifications of this global phenomenon have been compounded in Britain and the United States by the consequences of the quantitative easing programmes pursued by the Bank of England and the Federal Reserve Board. The large-scale purchase of government bonds and other securities from banks has fuelled a sharp range in a range of asset prices. As the Bank of England concluded in 2012, quantitative easing worth $£ 375$ billion in Britain has directly increased the value of assets of the richest 10 per cent of British households and the top five per cent in particular. ${ }^{2}$

In this context new taxes directed at wealth are an attractive proposition for politicians and officials. As wealth has risen over the past two decades the tax revenue yielded by existing wealth taxes has not kept pace. Even the International Monetary Fund has recommended that governments consider a one-off

${ }^{1}$ Credit Suisse Research Institute, Global Wealth Report 2014, October 2014, p. 4.

2 The Bank of England, The Distributional Effects of Asset Purchases, 12 July 2012. 
capital levy and commented that property taxes could be used more extensively both as a means of increasing tax revenue and redistributing wealth. ${ }^{3}$ Taxes on assets that are tied to a fixed place are particularly tempting for politicians. Houses cannot be taken offshore and, unlike average incomes, houses prices in many economies have recovered, particularly in those countries where the central bank has practiced extensive quantitative easing. On the left, the acclaim given to Thomas Piketty's recent book, Capital in the twenty-first century, in which he argues that the world is returning to a patrimonial capitalism based on concentrations on inherited wealth and advocates a global wealth tax as a policy response, has been evidence of the desire of increasing number of progressives for an approach to taxation that is more confiscatory towards the rich and begins with their assets.

In Britain, this general interest in asset taxes has been fortified by the particular and paradoxical nature of both the existing British tax regime and the near phenomenal rise in house prices in London over the past few years. On the first, compared to other developed countries taxes on property in Britain are high, both as a percentage of Gross Domestic Product and as a share of total tax revenue. Indeed, according to the OECD's 2014 Revenue Statistics, Britain had the highest property taxes in 2014 in the developed world. Yet the direct annual property tax levied on British houses, namely the council tax, is extremely generous to the rich, since the tax's bands for property value do not distinguish between a house worth millions of pounds and one valued at $£ 320$ oo1, an amount not that far above the national average house price and significantly below the average house price in London. Property in other cities like New York where the super-rich like to purchase houses as an investment asset is taxed on an annual basis at much higher rates than comparable houses in London. On the second, the British fiscal position would have been significantly worse since the recovery began if it were not for the revenue from stamp duty yielded by property purchases under conditions of rising house prices. Between January 2013 and September 2014 alone receipts from stamp duty rose by 71 per cent, the bulk of which came from London.

\section{Labour in the Liberal Democrats' footsteps}

Seen in this general light, Labour's recent embrace of a mansion tax is not difficult to explain. In principle, a tax that asks the rich pay more and is difficult to avoid plays well when the holders of expensive property have been among the beneficiaries of post-crisis policy and many are fed up with austerity practiced on the welfare state. Yet in practice Ed Miliband's announcement in his 2014 party conference speech that a

\footnotetext{
3 International Monetary Fund, Fiscal Policy and Income Inequality, 23 January 2014. p. 40.
} 
future Labour government would introduce a mansion tax on properties worth more than $£ 2$ million is of relatively little fiscal significance. This proposed mansion tax, even if its critics of its likely unintended consequences are wrong and it reaps the $£ 1.2$ billion envisaged, will make very little fiscal difference to a state that last year spent in the region of $£ 732$ billion, borrowed $£ 84$ billion, and paid $£ 53$ billion in interest on its debt. For all the symbolism of austerity for the rich and a turn towards taxing wealth the practical consequences thus far of Labour's adoption of a mansion tax rest instead in the manner in which the policy commitment has exposed a number of fault lines in Labour's position in the British political landscape.

The specific origins of the emergence of a mansion tax in British politics lie not in the Labour party but the Liberal Democrats, who went into the 2010 general election with a manifesto commitment to introduce an annual tax of 1 per cent on properties worth over $£ 2$ million. Since 2013 Labour’s own move towards a version of this policy stance has largely tracked the changing state of the relationship between the senior members of the two parties. Within the Liberal Democrats in government the leading proponent of pressing the Conservatives on the mansion tax within the Coalition has been Vince Cable, the Cabinet-level Liberal Democrat with whom most of the upper echelons of the Labour party would find it easiest to contemplate working in the future. As Cable made his views on the ongoing desirability of a mansion tax increasingly public in late 2012 and early 2013, the Labour leadership shifted its ground on the issue. In February 2013, Ed Miliband said for the first time that Labour would introduce a mansion tax with the specific purpose of paying for the introduction of a ten per cent starting income tax rate. With the apparent aim of trying to divide the Coalition partners before the Eastleigh by-election, Labour filed a motion in the House of Commons calling for the introduction of a mansion tax. Although in a number of interviews Cable stated that he did not rule out his party siding with Labour on the matter, when the parliamentary vote came the Liberal Democrats were able to find a position that kept them aligned with the Conservatives.

The Labour leadership returned to the issue in the summer of 2014, this time adding detail to the commitment to match the existing commitments in the Liberal Democrats' policy. In a column in the London Evening Standard, the Shadow Chancellor, Ed Balls, stated that Labour would introduce a progressive mansion tax to finance a new 10 per cent starting rate for income tax with separate bands for properties between $£ 2-5$ million, £5-10 million, £10-20 million, and £20 million and above. He also 
promised that the thresholds would 'be raised in line with average rises in house prices'. ${ }_{4}$ Again, this statement appeared to line up Labour's policy position with the Liberal Democrats' commitment to staggered bands as well as reinforcing common ground between the two parties about the desirability of income tax cuts for the least well paid in employment.

The 2014 conference season, however, put an end to this initial positioning on the mansion tax of both parties. Miliband in his speech committed Labour to a tax with a starting rate of $£ 12$ ooo a year for properties worth $£ 2$ million, but in doing so changed the revenue purpose of the tax from an income tax cut to additional spending on the National Health Service. By contrast, Nick Clegg said that the Liberal Democrats no longer supported a mansion tax and preferred instead to pursue council tax reform. It is perhaps not a coincidence that Clegg's u-turn came in the same week as various Liberal Democrats briefed the media that the party's leadership would now prefer another coalition with the Conservatives after the 2015 general election than a new one with Labour. With Miliband redirecting the proceeds of the tax to Labour's strongest electoral issue and Clegg commenting on the 'eye-watering amounts of tax' that would be paid on a mansion tax, both parties now seem much keener on policy demarcation in this area than alignment. 5

\section{Labour's Scotland-London cleavage}

If, however, a mansion tax is no longer the herald of rapprochement between Labour and the Liberal Democrats, it has become a charged catalyst for exposing some of Labour's internal party problems. In the aftermath of Miliband's already heavily disparaged conference speech, criticism of the policy from within the party appeared across the media. One large donor to the party, Lord Levy, damned the policy as 'totally inappropriate' whilst a number of Labour MPs representing London constituencies took to the airwaves to complain that the policy was a tax on the capital and took no account of those voters who had brought property in the city decades before and now thanks to house-price inflation found themselves asset rich and cash poor. ${ }^{6}$ In an attempt to defend the policy Ed Balls drew more censure when he responded to questioning on Sky's Murnaghan show by saying that in the future the thresholds would be

\footnotetext{
4 Ed Balls, 'A Mansion Tax will Make the Housing Market Fair for All,' London Evening Standard, 23 June 2014.

5 Sky News, ‘Liberal Democrats Want Council Tax Rise for Rich,’ 5 October 2014.

${ }^{6}$ Quoted in Guardian, 'Ed Balls defends Miliband's conference speech and mansion tax,' 5 October 2014.
} 
adjusted by national house price inflation without account of the much higher accelerating rate of increase prevailing in London. Balls was forced to respond by setting out the proposed mechanics of the tax in greater detail. Writing once again in the London Evening Standard, Balls adjusted Labour's position to try to counter the perception that the tax was unfair particularly as it pertained to London. This time he promised that there would be safeguards for basic income tax rate households, that the starting annual levy for the tax would be $£ 3000$ not the previously suggested $£ 12$ ooo, and that the thresholds would rise in line with the average rise in prices of high-value properties such that the number of properties effected would never increase from the number taxed on the day of its introduction.7

Many within the parliamentary party who represented London seats, however, remained unhappy, including all but one of those with aspirations to become Labour's next candidate for London mayor. This disquiet has also been evident in several Labour-run councils in the capital with Hammersmith and Fulham council passing a motion at the end of October 2014 to lobby against the tax on the grounds that it could result in some people having to sell their houses and leave the borough. Miliband's difficulties with the issue in late 2014 were compounded when, just days after he had seen off an apparent shadow cabinet revolt against his leadership, he struggled to defend the policy against the singer Myleene Klass on ITV's show 'The Agenda' when she proclaimed, among other things, that the super rich would use their accountants to get out of paying leaving the burden to fall on Londoners living in ordinary houses.

This apparent London problem was compounded in January 2015 when the new Scottish Labour leader, Jim Murphy, tweeted that the proceeds of a tax that would be primarily levied in south-east England would allow Labour to fund a thousand more nurses than any pledge made to increase nursing posts by the Scottish Nationalist Party (SNP). Taking to Radio Four's 'World at One' show, Diane Abbott, one of the aspiring mayoral candidates, said Murphy's announcement was 'highly unscrupulous' and he should not be 'expropriat[ing] money from Londoners to win an election in Scotland'. ${ }^{8}$ Immediately retaliating in kind, Murphy declared that he alone was responsible for decisions about how money that came to Scotland from British taxation was spent.

In introducing a Scottish element to what had hitherto been an internal issue for Labour in regard to London, Murphy exposed just how far the changing territorial politics of Britain has given Labour a set

7 Ed Balls, London Evening Standard, 'A mansion tax will be fair, simple, and pay to save the NHS,' 20 October 2014 .

${ }^{8}$ Quoted in Financial Times, 'London Labour MPs attack Scots' Plan to use mansion tax', 6 January 2015. 
of extremely difficult electoral headaches. The creation during the Blair years of both the Scottish executive and legislature and a London mayor have created distinct political spaces in two parts of Britain where since the 1980 os Labour has been disproportionately politically strong. Indeed, in the 2010 general election, Labour performed better in Scotland and London than anywhere else in the country. There can be no successful 35 per cent strategy for victory in 2015 if support in either crumbles. Yet in Scotland, first the arrival of an SNP majority government in 2011 and then the enormous swing towards the SNP since the independence referendum have left Labour in much weaker position than the party leadership could have conceived possible five years ago. In London, opinion polls and election results since the last general election, Boris Johnson's re-election aside, have been much better. But there is a clear potential for the other parties to exploit fear among London homeowners with properties worth more than $£ 1$ million about the operation of the future thresholds in relation to rising prices, including voters who have for years been core Labour supporters. There is also political capital to be made in the perception, captured graphically by Murphy's intervention, that London is being used as a tax cash cow to satisfy resentment of London's economic position in other parts of Britain. A YouGov poll conducted in the capital in late January 2015 for the London Evening Standard suggested that nearly three out of ten voters viewed Labour less favourably as a result of Murphy's remarks, with voters over 40 being especially negative. 9 In this context, it is possible that in embracing a mansion tax Labour has put at risk a number of marginal seats in London, in particular Hampstead and Highgate, Westminster North, Hammersmith, and Eltham, whilst making its nine target seats in the city more difficult.

In one sense, the Conservatives helped Labour diffuse the London argument with the stamp duty reform unveiled by Chancellor George Osborne in the 2014 autumn statement that left those purchasing properties worth more then $£ 937$ ooo, the large majority of whom will be in London, with more tax to pay. Politicians of all parties, it would seem, cannot resist trying to obtain more tax money out of the London housing market. They know that these moves incite fear among debt-laden middle-class homeowners in the capital, but there is little in the UK economy where what is available to tax is rising in value at anything like the same pace. Their partisan dispute is then over how far they will push. But within that debate Labour can still quite easily be politically portrayed as more hostile to the capital than other parties. As

${ }_{9}$ London Evening Standard, 'Jim Murphy's mansion tax boast will hurt Labour in London, poll finds,' 28 January 2015. 
Osborne reportedly said in responding to criticism about the effects on London of the top-end stamp duty hike: 'Londoners should be more worried about a mansion tax as it would be charged every year'. ${ }^{10}$

No proposed new tax has so quickly become attached to the politics of place within Britain since the third Thatcher government decided to introduce the poll tax a year earlier in Scotland than elsewhere, a moment that was in retrospect crucial to the ongoing breakdown of Scottish consent to the union. But the mansion tax's political potency comes not from being virulently unpopular among a large swathe of voters but rather the opportunities it gives to politicians to present themselves as the defenders of sectional territorial interests. As the Abbott-Murphy row showed politicians in the new territorial politics, even those seeking to represent parts of the union with the limited amount of devolved responsibility London enjoys, do not see themselves as bound to their party leaderships. In rowing with each other, Abbott and Murphy were demonstrating just how unconstrained either felt by the national Labour party, Abbott dissenting from official party policy, including casting doubt on whether the $£ 2$ million threshold would hold on which Labour's whole claim to fairness in regard to the tax rests, and Murphy loudly proclaiming that he did not have to consult Miliband about any pronouncements he wished to make as leader of Scottish Labour. At the height of New Labour in the late 1990s an Abbott-Murphy fight in which the pair took these respective positions on the desirability of a new tax on wealth would have been incomprehensible, given Murphy's support for the Blair project and Abbott's general dissent from it. But now the left-right ideological conflict within the Labour party has in part been rendered meaningless by the Scotland-London fault line.

This political tension can only get worse as the prospect of a possible Labour-SNP coalition after the general election takes shape. For a number of reasons Labour does have to prioritise holding onto as many as possible of its 41 seats in Scotland and in the event of failure to retain the option of forming some kind of agreement with the SNP that would allow it to govern without a parliamentary majority. But the more the leadership is seen to pursue this strategy, the harder it will become to contain dissent from London MPs and to see off the likely Conservative assault on the issue of English representation. As the Liberal Democrats discovered after the last election, a vote-winning strategy that for any length of time faces in two polar opposite political directions will eventually run its course to disaster. Having leeched long-established political capital in Scotland to maintain its deep commitment to the union, Labour is now

${ }^{10}$ Quoted in London Evening Standard, 'The capital must not be the Treasury's cash cow', 4 December 2014. 
at the mercy of its ability to repair the damage quickly. The longer Labour's Scottish problems go on and the longer Scottish Labour has the incentive to find differences with London to strengthen its nationalist credentials, the greater the risk that Labour loses not just support in London but England more generally. As UKIP has demonstrated, there may be much to be gained in the domestic politics of England by attacks on a metropolitan elite based in the capital. But this is a much riskier political strategy to pursue when the party concerned has 38 seats in London and meanwhile wants the West Lothian question to go away even as Scotland receives new devolved powers. One only has to imagine a scenario in which under some form of coalition with the SNP a future Labour government was pressed into extending the reach of the tax to properties under the presently proposed threshold to see what could be at stake for the party's position in England from this kind of politics.

\section{Conclusions: internationalisation and the avoidance of radicalism}

In short a tax that would raise rather little revenue has the potential to cause a serious substantive problem for Labour that would get to the heart of the legitimacy issue now raised by the possibility of Labour governing under the post-referendum territorial settlement without an English majority. There is a gap here between the intrinsic policy stakes and the political posturing and its consequences generated by the issue. This distance has a clear parallel in the general problem Labour have had under Miliband's leadership in matching up Miliband and the Shadow Cabinet's rhetorical lines of attack with the alternative policies offered. Miliband's political language is the discourse of crisis and the desperate need for structural reform of the economy to reduce inequality. In Miliband's view, Britain suffers not just from a Conservative-led government that has privileged the rich over the poor in its economic policy-making but a dysfunctional national capitalism. Yet there is nothing in the policies he has thus far offered from the mansion tax to freezing energy prices that would remotely amount to a radical economic programme aimed at addressing what is purportedly so badly wrong.

In part this imbalance seems the result of Miliband's political upbringing under Gordon Brown and the former Prime Minister's obsession with finding dividing lines between Labour and the Conservative and making them the point of policy and the basis of fierce political attack regardless of the size of the difference. But the failure to close the gap between crisis rhetoric and only symbolically-charged policies also reflects the difficulties politicians of the left have in getting to grips with issues of the concentration of wealth and the cronyism of corporate-state relationships in a world economically dominated by finance. 
There can be no radical change without serious engagement with the ways in which the state itself has been captured by, and made itself dependent on, an array of private, corporate interests tied to the financial sector. The state is reliant on the immediate material reward, including the fiscal revenue and capital for investment, that these interests offer, but this bounty comes at a high price. In the post-crisis world the left has also been floundered on the issue of quantitative easing, criticising, as it has, both austerity and the recent rise in inequality, a disparity of wealth that has in good part been fuelled by the same printing of money that has also kept interest rates low and borrowing conditions for governments benign, thus reducing the pressure for governments to reduce budget deficits further with more austerity. Miliband is perhaps particularly reluctant to engage with the consequences of internationalised financial sectors supported by central bank printing machines given his apparent conviction that if only Britain could shift to a German variety of capitalism, which he seems to think in the face of the acute difficulties of German banks escapes the problem, the reform job would be done. He is also naïve in thinking that the palpable gap between his radical rhetoric and gesture policies is not a political liability, both in helping to push more left-wing voters towards the Greens and casting further doubt on his capacity for basic governing competence. But he is far from alone in his political paralysis.

Present democratic politics in Europe and North America is ill suited to confront the economic world in which we live at least until as in Greece near total crisis arrives. In Britain, the political class has little idea how to address the consequences of the flow of international capital into London particularly in regard to the use of London houses as investment assets. Indeed, the preference of most politicians at Westminster appears to be to encourage the city's internationalisation and hope the consequences will go away. Nowhere can this been seen more clearly than the tax treatment of non-residents. Whilst foreign investment capital has since the crisis fuelled the London housing boom, the Labour leadership has made no significant political criticism of the exemption of non-residents from capital gains tax. Meanwhile George Osborne made his 2013 proposal to end this dispensation subject to a long consultation process with those he calls 'stakeholders'. The outcome of the protracted chance for all those affected to complain was a policy designed in the Treasury's words, to 'avoid placing undue burdens on taxpayers' and which grants exemptions to institutional investors and excludes any capital gain made before April $2015 \cdot{ }^{11}$

${ }^{11}$ HM Treasury, Implementing a Capital Gains Tax on Non-Residents: A Summary of Responses, (London: HM Treasury), p. 2. 
But neither can democratic politics easily absorb the fallout of this approach to taxing foreign capital. In its own terms, the potentially biggest political problem generated by Labour's mansion tax is the argument that when the tax is in practice paid only by those actually living in the houses subject to the levy the $£ 2$ million threshold will be adjusted downwards to provide the revenue promised. Fiscal drag, whether as has happened on the 40 per cent rate of income tax or stamp duty over the past decade or so, is now what many people expect will happen when politicians establish new top-level thresholds or new taxes. The narrative that the middle classes will bear the tax burden created by a political class that is willing neither to make the super-rich pay sufficient tax nor disavow additional spending and redistribution towards lower income households whilst its members look to enrich themselves in their post-politics careers with the entry cards to the same internationalised economic elite yielded by their time in office is one that in coming years will become increasingly hard to rebut. Its resonance damages both the legitimacy of a tax state that no longer seems based on impersonal rules and the idea of a national democratic politics that can recognise any distinction between public and private interests. 